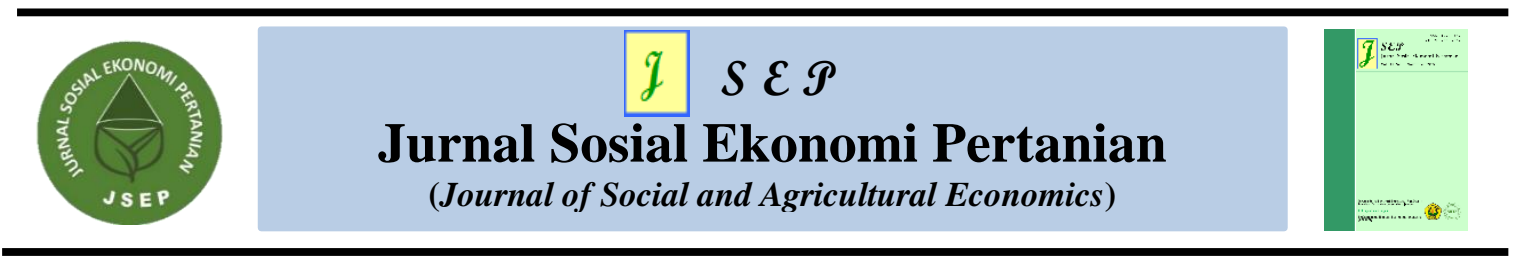

\title{
PERSEPSI PETANI TERHADAP PENGGUNAAN PUPUK KOMPOS PADA USAHATANI PADI DI KELOMPOK TANI HARAPAN DESA POGALAN KECAMATAN POGALAN KABUPATEN TRENGGALEK
}

\section{PERCEPTION OF FARMERS ON THE USE OF COMPOST ON RICE FARMING IN HARAPAN FARMER GROUPS, POGALAN VILLAGE, POGALAN SUB DISTRICT, TRENGGALEK REGENCY}

\author{
Naudya Wulan Aprilianti ${ }^{1 *}$, Sutoyo ${ }^{1}$, Eny Wahyuning Purwanti ${ }^{1}$ \\ ${ }^{1}$ Program Studi Penyuluhan Pertanian Berkelanjutan, Politeknik Pembangunan Pertanian Malang \\ *email: naudya.wulan14@gmail.com; 082336762577
}

\begin{abstract}
Compost fertilizer is fertilizer that comes from the remains of organic matter through a decomposition process with the aim of improving soil structure. This research aimed to determine farmers' perceptions of the use of compost on rice farming, the influence of internal factors and external factors on the perceptions of farmers in using compost on rice farming, and the design of extension and use of compost fertilizer on rice farming to determine the perceptions of farmers on the use of compost fertilizer on rice farming. The research method used is the survey method. The sampling method uses purposive sampling method. The results of this study showed that the highest perception received was 57,1\% based on making compost, the age and experience of rice farming do not affect farmers' perceptions, and the design of counseling uses the material for making also using compost on rice farming; the methods used are visual, audio visual, lecture, and discussion; the media used is film.
\end{abstract}

Keywords: extension design, farmer's perceptions, use of compost fertilizer

\begin{abstract}
ABSTRAK
Pupuk kompos adalah pupuk yang berasal dari sisa-sisa bahan organik melalui proses dekomposisi dengan tujuan memperbaiki struktur tanah. Penelitian ini bertujuan untuk mengetahui persepsi petani terhadap penggunaan pupuk kompos pada usahatani padi, pengaruh faktor internal dan faktor eksternal terhadap persepsi petani dalam penggunaan pupuk kompos pada usahatani padi, dan rancangan penyuluhan pembuatan dan penggunaan pupuk kompos pada usahatani padi untuk mengetahui persepsi petani terhadap penggunaan pupuk kompos pada usahatani padi. Metode penelitian yang digunakan adalah metode survei. Metode pengambilan sampel menggunakan metode purposive sampling. Hasil penelitian ini menunjukkan bahwa persepsi tertinggi yang menerima sebesar $57,1 \%$ berdasarkan pembuatan pupuk kompos, umur dan pengalaman berusahatani padi tidak berpengaruh terhadap persepsi petani, dan rancangan penyuluhan menggunakan materi pembuatan serta penggunaan pupuk kompos pada usahatani padi; metode yang digunakan adalah visual, audio visual, ceramah, dan diskusi; media yang digunakan adalah film.
\end{abstract}

Kata kunci: penggunaan pupuk kompos, persepsi petani, rancangan penyuluhan

How to Cite: Aprilianti, N.W., Sutoyo, \& Purwanti, E.W. (2020). Persepsi Petani Terhadap Penggunaan Pupuk Kompos Pada Usahatani Padi di Kelompok Tani Harapan Desa Pogalan Kecamatan Pogalan Kabupaten Trenggalek. JSEP: Jurnal Sosial Ekonomi Pertanian, 13(2): 173-181. 


\section{PENDAHULUAN}

Persepsi adalah proses pemilihan, penafsiran, maupun peratusan serta pengaturan informasi indrawi tentang orang lain. Persepsi dalam arti sempit yaitu suatu penglihatan yang artinya, bagaimana cara seseorang memandang atau melihat sesuatu, sedangkan persepsi dalam arti luas yaitu pandangan, yang dijelaskan menjadi bagaimana seseorang memandang atau mengartikan sesuatu (Sobur, 2016). Perilaku merupakan cara bertindak yang menunjukkan tingkah laku dan merupakan hasil kombinasi antara pengembangan anatomis, fisiologis dan psikologis. Perilaku petani merupakan cara bertindak dalam berusahatani (Sugiyono, 2010).

Perantara rangsangan di luar organisme dengan tanggapan fisik organisme yang dapat diamati terhadap rangsangan merupakan salah satu pandangan yang dianut secara luas menyatakan bahwa psikologi sebagai telaah ilmiah berhubungan dengan unsur dan proses. Persepsi adalah bagian dari keseluruhan proses yang menghasilkan tanggapan setelah rangsangan diterapkan kepada manusia yang dikenal dengan (Sobur, 2016).

Penggunaan pupuk anorganik dengan takaran yang melebihi ketentuan membuat berubahnya tekstur dan struktur tanah. Tanah menjadi sulit diolah dan tanah bersifat masam. Kondisi tanah masam akan menghambat mobilisasi unsur hara yang terikat sehingga produktivitas tanaman menjadi rendah (Nasir, 2008).

Kompos adalah pupuk yang berasal dari sisa-sisa bahan organik. Kompos dapat memperbaiki struktur tanah dan sifat fisik tanah, meningkatkan daya untuk menahan air, kimia tanah dan biologi tanah. Sumber bahan pupuk kompos antara lain berasal dari limbah organik seperti sisa-sisa tanaman (jerami, batang, dahan), sampah rumah tangga, kotoran ternak (sapi, kambing, ayam, itik), arang sekam, abu dapur dan lain-lain (Rukmana, 2007).

Penggunaan kompos yang merupakan bahan pembenah tanah (soil conditioner) dapat meningkatkan kandungan bahan organik tanah sehingga kesuburan tanah pertanian dapat dipertahankan dan meningkat. Karakteristik kompos secara umum antara lain: (1) mengandung unsur hara dalam jenis Pupuk Organik dan Pupuk Hayati serta jumlah yang bervariasi tergantung bahan asal; (2) menyediakan unsur hara secara lambat (slow release) dalam jumlah terbatas; dan (3) mempunyai fungsi utama memperbaiki kesuburan dan kesehatan tanah (Indriani, 2002)

Perubahan kebiasaan penggunaan pupuk anorganik dengan pupuk organik memerlukan waktu yang lama. Petani harus mempunyai persepsi bahwa dengan menggunakan bahan-bahan organik yang telah di daur ulang sebagai sarana produksi dalam berusahatani, secara perlahan-lahan dapat memperbaiki kembali kondisi lahan yang telah mengalami degradasi untuk berproduksi. Padi merupakan komoditas utama yang diusahakan oleh sebagian besar petani di Desa Pogalan Kecamatan Pogalan Kabupaten Trenggalek. Perubahan kebiasaan penggunaan pupuk di Desa Pogalan melalui pengaruh faktor internal dan faktor eksternal. Faktor eksternal mempunyai sifat yang berasal dari luar, sedangkan faktor internal menunjukkan sifat dari dalam. Perubahan tersebut membutuhkan waktu yag relatif lama hingga petani padi di Desa Pogalan bersedia untuk menggunakan pupuk kompos pada usahataninya. Hal ini pun menimbulkan pro dan kontra antar petani. Berdasarkan latar belakang tersebut, menjadi penting untuk meneliti persepsi petani terhadap penggunakan pupuk kompos di Desa Pogalan.

Penelitian mengenai persepsi petani terhadap penggunaan pupuk sudah pernah dilakukan oleh (Basri, 2016); (Agustian, A.; Benny, 2006); (Gama, I.G.M.; Oktaviani, R.; Arifin, 2016); (Sam, U.S.; Ali, M.S.S.; Arsyad, 2018); (Hadi, S.; Akhmadi, A.N.; 
Prayuningsih, 2019); (Intisar;, Ayu, S.M.; Rosnina; Nuryanti, 2019); (Wasito; Sarwani, M.; Ananto, 2010); dan (Tedjaningsih, T.; Suyudi; Nuryaman, 2017). Penelitianpenelitian tersebut menunjukkan bahwa persepsi petani terhadap penggunakan pupuk organik atau bokasi di beberapa wilayah di Indonesia masih bersifat negatif dan cenderung enggan menggunakannya walaupun beberapa penelitian menunjukkan adanya respon yang positif terdahap penggunaan pupuk organic tersebut. Penelitian sebelumnya lebih banyak mengungkap mengenai respon penggunakan pupuk tanpa melihat pengaruh faktor-faktor yang mempengaruhi persepsi tersebut. Adapun kebaharuan pada penelitian ini selain menganalisi mengenai persepsi terhadap penggunaan pupuk, penelitian ini juga membahas mengenai faktor-faktor yang berpengaruh terhadap persepsi serta rancangan penyuluhan seperti apa yang efektif agar petani mau untuk menggunakan pupuk kompos tersebut.

Tujuan dari penelitian ini adalah untuk mengetahui (1) persepsi petani terhadap penggunaan pupuk kompos pada usahatani padi, (2) pengaruh faktor internal dan faktor eksternal terhadap persepsi petani dalam penggunaan pupuk kompos pada usahatani padi, dan (3) rancangan penyuluhan pembuatan dan penggunaan pupuk kompos pada usahatani padi untuk mengetahui persepsi petani terhadap penggunaan pupuk kompos pada usahatani padi.

\section{METODE PENELITIAN}

Penentuan daerah pada penelitian ini ditentukan dengan sengaja (purposive sampling) yaitu di Kelompoktani Harapan Desa Pogalan Kecamatan Pogalan Kabupaten Trenggalek. Pemilihan daerah penelitian ini berdasarkan pertimbangan bahwa di Kelompoktani Harapan memiliki potensi bahan dasar pupuk kompos yang tidak diolah serta penggunaan pupuk yang diaplikasikan pada usahatani padi adalah pupuk anorganik. Kondisi pada saat penelitian yaitu penggunaan kompos disamping kondisi di lapangan sebelum penelitian yang hanya menggunakan pupuk an organik. Penelitian ini dilakukan pada bulan Maret-Juni 2019.

Metode penelitian yang digunakan adalah metode survei. Metode pengambilan sampel yang digunakan dalam penelitian ini adalah persepsi petani terhadap penggunaan pupuk kompos pada usahatani padi di Kelmpoktani Harapan Desa Pogalan Kecamatan Pogalan Kabupaten Trenggalek. Petani di Kelompoktani Harapan memiliki beberapa persepsi kemudian dipilih dengan cara sengaja (purposive sampling) sampel terbagi dari pupuk kompos dan pupuk an organik.

Data yang digunakan dalam penelitian ini yaitu data primer dan data sekunder. Data primer adalah data yang diperoleh secara langsung dari responden maupun dari pihakpihak yang terkait dengan cara mewawancarai langsung berdasarkan kuisioner yang telah disiapkan. Data sekunder adalah data yang diperoleh dari analisis dan pemeriksaan, baik berupa peraturan perundang-undangan, data statistik, monografi desa, programa, dan studi pustaka. Pengambilan data sekunder melalui Kantor Desa dan Balai Penyuluhan Pertanian (BPP).

Pengujian permasalahan pertama mengenai persepsi petani terhadap penggunaan pupuk kompos pada usahatani padi yaitu menggunakan skor Terstandar (T-score) dengan rumur sebagai berikut (Azwar, 2015):

$$
\mathrm{T}=50+10(\mathrm{Z})
$$

Keterangan:

$\mathrm{T}=$ Skor Terstandar (T-score)

$\mathrm{Z} \quad=$ Skor Standar (Z-score) 
Skor Standar (Z-score) menggunakan rumus sebagai berikut (Azwar, 2016):

Keterangan:

$$
\mathrm{Z}=\frac{(\mathrm{Yi}-\overline{\mathrm{Y}})}{S D}
$$

$\mathrm{Z}=$ Skor Standar (Z-score)

$\mathrm{Yi}=$ Skor mentah

$\bar{Y}=$ Mean awal

$\mathrm{SD}=$ Deviasi standar awal

Metode analisis yang digunakan untuk menguji permasalahan kedua yaitu menggunakan analisis regresi logistik yang mengenai pengaruh faktor internal dan faktor eksternal terhadap persepsi petani dalam penggunaan pupuk kompos pada usahatani padi. Analisis regresi logistik dalam penelitian ini menggunakan software SPSS. Dalam penelitian ini variabel bebas yang diukur adalah sebagai berikut: (1) umur, (2) tingkat pendidikan, (3) pengalaman berusahatani padi, (4) pemilikan lahan, (5) pengetahuan petani terhadap pupuk organik, (6) intensitas pelatihan, (7) intensitas penyuluhan, (8) intensitas kunjungan atau magang, dan (9) ketersediaan sarana dan prasarana dalam berusahatani. Variabel terikat dalam penelitian ini adalah persepsi dengan 3 kategori yaitu: (1) manfaat, (2) pembuatan pupuk kompos, dan (3) aplikasi pupuk kompos. Jumlah responden dalam penelitian ini adalah 35 responden. Analisis regresi dapat diformulasikan sebagai berikut:

$$
Y(x)=\ln \left(\frac{y(x)}{1-y(x)}\right)=\beta_{0}+\beta_{1} X_{1}+\beta_{2} X_{2}+\beta_{3} X_{3}+\beta_{4} X_{4}+\beta_{5} X_{5}+\beta_{6} X_{6}+\beta_{7} X_{7}+\beta_{8} X_{8}+\beta_{9} X_{9}
$$

Keterangan :

$\mathrm{Y}=$ Keputusan Petani menggunakan pupuk kompos (Variabel Dummy)

$(0=$ tidak menggunakan pupuk kompos, $1=$ menggunakan pupuk kompos)

$\beta=$ konstanta

$\mathrm{X}_{1}=$ umur petani (tahun)

$\mathrm{X}_{2}=$ Tingkat pendidikan (tahun)

$\mathrm{X}_{3}=$ pengalaman berusahatani padi (tahun)

$\mathrm{X}_{4}=$ kepemilikan lahan

$\mathrm{X}_{5}=$ pengetahuan petani terhadap pupuk organik

$\mathrm{X}_{6}=$ intensitas pelatihan

$\mathrm{X}_{7}$ =intesitas peyuluhan

$\mathrm{X}_{8}=$ intensitas kunjungan atau magang

$\mathrm{X}_{9}=$ ketersediaan sarana dan prasarana dalam berusahatani

\section{HASIL DAN PEMBAHASAN}

Persepsi Petani Terhadap Penggunaan Pupuk Kompos Pada Usahatani Padi

Analisis deskriptif persepsi menggunakan skor T dalam penelitian ini menghasilkan analisis data persepsi petani sebagai berikut:

Tabel 1. Analisis Deskriptif Skor T Persepsi Berdasarkan Manfaat

\begin{tabular}{ccc}
\hline Persepsi & Frekuensi & Presentase (\%) \\
\hline Menolak (0) & 16 & 45.7 \\
Menerima (1) & 19 & 54.3 \\
\hline Jumah & $\mathbf{3 5}$ & $\mathbf{1 0 0 . 0}$ \\
\hline
\end{tabular}

Berdasarkan manfaat, diketahui bahwa 16 petani memiliki persepsi yang menolak dengan presentase $45.7 \%$ sedangkan 19 orang petani memiliki persepsi yang menerima 
dengan presentase $54.3 \%$. Persepsi menolak artinya petani menolak terhadap penggunaan pupuk kompos pada usahatani padi. Persepsi menerima artinya responden menerima terhadap penggunaan pupuk kompos pada usahatani padi.

Tabel 2. Analisis Deskriptif Skor T Persepsi Berdasarkan Pembuatan Pupuk Kompos

\begin{tabular}{ccc}
\hline Persepsi & Frekuensi & Presentase (\%) \\
\hline Menolak (0) & 15 & 42.9 \\
Menerima (1) & 20 & 57.1 \\
\hline Jumah & $\mathbf{3 5}$ & $\mathbf{1 0 0 . 0}$
\end{tabular}

Berdasarkan pembuatan pupuk kompos, diketahui bahwa 15 petani persepsi yang menolak dengan presentase $42.9 \%$ sedangkan 20 orang petani memiliki persepsi yang menerima dengan presentase $57.1 \%$. Persepsi menolak artinya petani menolak terhadap penggunaan pupuk kompos pada usahatani padi. Persepsi menerima artinya responden menerima terhadap penggunaan pupuk kompos pada usahatani padi.

Tabel 3. Analisis Deskriptif Skor T Persepsi Berdasarkan Aplikasi Pupuk Kompos

\begin{tabular}{ccc}
\hline Persepsi & Frekuensi & Presentase (\%) \\
\hline Menolak (0) & 20 & 57.1 \\
Menerima (1) & 15 & 42.9 \\
\hline Jumah & $\mathbf{3 5}$ & $\mathbf{1 0 0 . 0}$
\end{tabular}

Berdasarkan aplikasi pupuk kompos, diketahui bahwa 20 petani persepsi yang menolak dengan presentase $57.1 \%$ sedangkan 15 orang petani memiliki persepsi yang menerima dengan presentase $42.9 \%$. Persepsi menolak artinya petani menolak terhadap penggunaan pupuk kompos pada usahatani padi. Persepsi menerima artinya responden menerima terhadap penggunaan pupuk kompos pada usahatani padi.

\section{Pengaruh Faktor Internal dan Faktor Eksternal Terhadap Persepsi Petani}

Analisis regresi logistik menggunakan variable biner yaitu ya dan tidak untuk mengetahui pengaruh faktor internal dan faktor eksternal terhadap penggunaan pupuk kompos dalam penelitian ini menghasilkan data sebagai berikut:

Tabel 4. Hasil Analisis Faktor yang Mempengaruhi Penggunaan Pupuk Kompos

\begin{tabular}{|c|c|c|c|c|}
\hline Variabel & $\begin{array}{c}\text { Koefisien } \\
\text { B } \\
\end{array}$ & $\begin{array}{c}\text { Nilai Uji } \\
\text { Wald }\end{array}$ & $\begin{array}{c}\text { Prob. Uji } \\
\text { Wald }\end{array}$ & $\begin{array}{c}\text { Koefisien } \\
\text { Exp. B } \\
\end{array}$ \\
\hline Umur (tahun) & -0.080 & 1.585 & 0.208 & 0.923 \\
\hline Tingkat Pendidikan & $2.905 *$ & 3.892 & 0.049 & 18.270 \\
\hline Pengalaman Berusahatani Padi (tahun) & 0.104 & 2.002 & 0.157 & 1.109 \\
\hline Pemilikan Lahan & $3.454 *$ & 4.381 & 0.036 & 31.621 \\
\hline $\begin{array}{l}\text { Pengetahuan Petani Terhadap Pupuk } \\
\text { Organik }\end{array}$ & $9.014 * *$ & 7.213 & 0.007 & $8.214 \times 10^{3}$ \\
\hline Intensitas Pelatihan & $-5.264 * *$ & 6.724 & 0.010 & 0.005 \\
\hline Intensitas Penyuluhan & $-6.039 * *$ & 7.024 & 0.008 & 0.002 \\
\hline Intensitas Kunjungan atau Magang & $-3.909 *$ & 4.400 & 0.036 & 0.020 \\
\hline $\begin{array}{l}\text { Ketersediaan Sarana dan Prasarana dalam } \\
\text { Berusahatani }\end{array}$ & $-3.645^{*}$ & 5.060 & 0.024 & 0.026 \\
\hline Konstanta & 8.456 & 3.636 & 0.057 & $4.702 \times 10^{3}$ \\
\hline
\end{tabular}

Keterangan: *(signifikan pada taraf $\alpha=5 \%) ; * *($ signifikan pada taraf $\alpha=1 \%)$ 


\section{Pengaruh Umur Terhadap Persepsi Petani}

Variabel umur merupakan variabel yang terdapat dari faktor internal. Hasil penelitian menunjukan nilai signifikansi variabel umur adalah $0,208(>0,05)$ yang berarti bahwa variabel umur tidak berpengaruh signifikan terhadap persepsi petani terhadap penggunaan pupuk kompos pada usahatani padi. Nilai exp. B (rasio peluang beta) adalah 0,923 menunjukan bahwa nilainya positif maka dapat diartikan bahwa umur tidak berpengaruh positif terhadap persepsi petani. Hal ini mengakibatkan adanya kesalahan persepsi. Adapun faktor yang berpengaruh terhadap kesalahan persepsi yaitu Hallo effect yang artinya kecenderungan menilai seseorang hanya atas dasar salah satu sifatnya.

\section{Pengaruh Tingkat Pendidikan Terhadap Persepsi Petani}

Variabel tingkat pendidikan merupakan variabel yang terdapat dari faktor internal. Hasil penelitian menunjukan nilai signifikansi variabel tingkat pendidikan adalah 0,049 $(<0,05)$ yang berarti bahwa variabel tingkat pendidikan berpengaruh signifikan terhadap persepsi petani terhadap penggunaan pupuk kompos pada usahatani padi. Nilai exp. B (rasio peluang beta) adalah 18,270 menunjukan bahwa nilainya positif maka dapat diartikan bahwa tingkat pendidikan berpengaruh positif terhadap persepsi petani.

\section{Pengaruh Pengalaman Berusahatani Padi Terhadap Persepsi Petani}

Variabel pengalaman berusahatani padi merupakan variabel yang terdapat dari faktor internal. Hasil penelitian menunjukan nilai signifikansi variabel pengalaman berusahatani padi adalah 0,157 (> 0,05) yang berarti bahwa variabel pengalaman berusahatani padi tidak berpengaruh signifikan terhadap persepsi petani terhadap penggunaan pupuk kompos pada usahatani padi. Nilai exp. B (rasio peluang beta) adalah 1,109 menunjukan bahwa nilainya positif maka dapat diartikan bahwa pengalaman berusahatani padi tidak berpengaruh positif terhadap persepsi petani. Adapun faktor yang berpengaruh terhadap kesalahan persepsi yaitu stereotyping mengkategorikan atau menilai seseorang hanya atas dasar satu atau beberapa sifat dari kelompoknya.

\section{Pengaruh Pemilikan Lahan Terhadap Persepsi Petani}

Variabel pemilikan lahan merupakan variabel yang terdapat dari faktor internal. Hasil penelitian menunjukan nilai signifikansi variabel pemilikan lahan adalah 0,036 (< 0,05) yang berarti bahwa variabel pemilikan lahan berpengaruh signifikan terhadap persepsi petani terhadap penggunaan pupuk kompos pada usahatani padi. Nilai exp. B (rasio peluang beta) adalah 31,621 menunjukan bahwa nilainya positif maka dapat diartikan bahwa pemilikan lahan berpengaruh positif terhadap persepsi petani.

\section{Pengaruh Pengetahuan Petani Terhadap Pupuk Organik Terhadap Persepsi Petani}

Variabel pengetahuan petani terhadap pupuk organik merupakan variabel yang terdapat dari faktor internal. Hasil penelitian menunjukan nilai signifikansi variabel pengetahuan petani terhadap pupuk organik adalah $0,07(<0,05)$ yang berarti bahwa variabel pengetahuan petani terhadap pupuk organik berpengaruh signifikan terhadap persepsi petani terhadap penggunaan pupuk kompos pada usahatani padi. Nilai exp. B (rasio peluang beta) adalah 8,214 menunjukan bahwa nilainya positif maka dapat diartikan bahwa pengetahuan petani terhadap pupuk organik berpengaruh positif terhadap persepsi petani. 


\section{Pengaruh Intensitas Pelatihan Terhadap Persepsi Petani}

Variabel intensitas pelatihan terhadap pupuk organik merupakan variabel yang terdapat dari faktor eksternal. Hasil penelitian menunjukan nilai signifikansi variabel intensitas pelatihan adalah $0,010(<0,05)$ yang berarti bahwa variabel intensitas pelatihan berpengaruh signifikan terhadap persepsi petani terhadap penggunaan pupuk kompos pada usahatani padi. Nilai exp. B (rasio peluang beta) adalah 0,005 menunjukan bahwa nilainya positif maka dapat diartikan bahwa intensitas pelatihan berpengaruh positif terhadap persepsi petani.

\section{Pengaruh Intensitas Penyuluhan Terhadap Persepsi Petani}

Variabel intensitas penyuluhan terhadap pupuk organik merupakan variabel yang terdapat dari faktor eksternal. Hasil penelitian menunjukan nilai signifikansi variabel intensitas penyuluhan adalah 0,008 $(<0,05)$ yang berarti bahwa variabel intensitas penyuluhan berpengaruh signifikan terhadap persepsi petani terhadap penggunaan pupuk kompos pada usahatani padi. Nilai exp. B (rasio peluang beta) adalah 0,002 menunjukan bahwa nilainya positif maka dapat diartikan bahwa intensitas penyuluhan berpengaruh positif terhadap persepsi petani.

\section{Pengaruh Intensitas Kunjungan atau Magang Terhadap Persepsi Petani}

Variabel intensitas kunjungan atau magang terhadap pupuk organik merupakan variabel yang terdapat dari faktor eksternal. Hasil penelitian menunjukan nilai signifikansi variabel intensitas kunjungan atau magang adalah $0,036(<0,05)$ yang berarti bahwa variabel intensitas kunjungan atau magang berpengaruh signifikan terhadap persepsi petani terhadap penggunaan pupuk kompos pada usahatani padi. Nilai exp. B (rasio peluang beta) adalah 0,020 menunjukan bahwa nilainya positif maka dapat diartikan bahwa intensitas kunjungan atau magang berpengaruh positif terhadap persepsi petani.

\section{Pengaruh Ketersediaan Sarana dan Prasarana dalam Berusahatani Terhadap Persepsi Petani}

Variabel ketersediaan sarana dan prasarana dalam berusahatani terhadap pupuk organik merupakan variabel yang terdapat dari faktor eksternal. Hasil penelitian menunjukan nilai signifikansi variabel ketersediaan sarana dan prasarana dalam berusahatani adalah $0,024(<0,05)$ yang berarti bahwa variabel ketersediaan sarana dan prasarana dalam berusahatani berpengaruh signifikan terhadap persepsi petani terhadap penggunaan pupuk kompos pada usahatani padi. Nilai exp. B (rasio peluang beta) adalah 0,026 menunjukan bahwa nilainya positif maka dapat diartikan bahwa ketersediaan sarana dan prasarana dalam berusahatani berpengaruh positif terhadap persepsi petani.

\section{Rancangan Penyuluhan}

Sasaran penyuluhan merupakan anggota kelompoktani Harapan Desa Pogalan Kecamatan Pogalan Kabupaten Trenggalek yang merupakan anggota aktif. Sasaran telah melaksanakan usahatani padi serta mengetahui pemupukan pada usahatani padi menggunakan pupuk kompos melalui penyuluhan. Selain itu, sasaran yang merupakan responden dari penelitian ini telah ikut serta dalam kegiatan pelaksanaan penyuluhan tentang pembuatan dan penggunaan pupuk kompos pada usahatani padi dari penyuluh wilayah binaan Desa Pogalan setempat. Sasaran utama penyuluhan merupakan 35 petani yang aktif dan merupakan responden dari penelitian. 
Tujuan penyuluhan merupakan penetapan hasil kajian yang dirancang untuk kegiatan pelaksanaan penyuluhan. Tujuan penyuluhan pada penelitian ini yaitu agar petani memahami bagaimana cara pembuatan dan pengaplikasian pupuk kompos pada usahatani padi. Sehingga petani dapat menghasilkan hasil produksi sesuai yang diharapkan dibandingkan dengan menggunakan pupuk anorganik. Selain itu tujuan akhir dari penyuluhan adalah petani dapat mengambil sikap yang sesuai diharapkan dalam usahatani padi agar menggunakan pupuk kompos dan tidak bergantung pada pupuk anorganik.

Materi penyuluhan dalam penelitian ini dipilih berdasarkan solusi dari masalah yang disimpulkan atas identifikasi potensi wilayah serta berdasarkan hasil analisis data penelitian. Materi penyuluhan dalam penelitian ini adalah pembuatan pupuk kompos serta penggunaannya pada usahatani padi di lahan petani kelompoktani Harapan. Materi yang ditetapkan merupakan kebutuhan dari sasaran untuk mencapai tujuan penyuluhan.

Metode penyuluhan dalam penelitian ini di kelompoktani Harapan yaitu visual, audio visual, ceramah dan diskusi. Metode visual, audio visual, ceramah, dan diskusi melibatkan interaksi antar anggota yang mengikuti pelaksanaan penyuluhan. Metode tersebut merupakan metode yang efektif dalam pelaksanaan penyuluhan di kelompoktani Harapan agar petani mudah memahami materi penyuluhan.

Media penyuluhan dalam penelitian yaitu film yang ditanyangkan menggunakan LCD dan proyektor. Film merupakan inovasi dari media penyuluhan di kelompoktani Harapan. Media film belum pernah digunakan dalam pelaksanaan penyuluhan di kelompoktani Harapan. Media film bertujuan agar petani dapat lebih tertarik terhadap materi penyuluhan mengenai pembuatan dan penggunaan pupuk kompos pada usahatani padi.

\section{KESIMPULAN}

Persepsi petani terhadap penggunaan pupuk kompos pada usahatani padi yang tertinggi menerima yaitu berdasarkan pembuatan pupuk kompos dengan presentase $57.1 \%$. Persepsi petani terhadap penggunaan pupuk kompos pada usahatani padi tertinggi kedua yang menerima yaitu berdasarkan manfaat dengan presentase $54.3 \%$. Persepsi petani terhadap penggunaan pupuk kompos pada usahatani padi terendah yang menerima yaitu berdasarkan aplikasi pupuk kompos dengan presentase $42.9 \%$. Variabel yang berpengaruh memiliki nilai signifikan kurang dari $0.05(<0.05)$. Variabel yang berpengaruh positif memiliki nilai exsponen yang positif. Variabel faktor internal yang berpengaruh positif terhadap persepsi dalam penelitian ini adalah: (1) tingkat pendidikan dengan nilai signifikasi 0.049, (2) pemilikan lahan dengan nilai signifikasi 0.036, (3) dan pengetahuan petani terhadap pupuk organik dengan nilai signifikasi 0.007. Variabel faktor internal yang tidak berpengaruh terhadap persepsi dalam penelitian ini adalah: (1) umur dengan nilai signifikasi 0.208 , dan (2) pengalaman berusahatani padi dengan nilai signifikasi 0.157 . Variabel faktor eksternal yang berpengaruh positif terhadap persepsi dalam penelitian ini adalah: (1) intensitas pelatihan dengan nilai signifikasi 0.010 , (2) intensitas penyuluhan dengan nilai signifikasi 0.008 , (3) intensitas kunjungan atau magang dengan nilai signifikasi 0.036, dan (4) ketersediaan sarana dan prasarana dalam berusahatani dengan nilai signifikasi 0.024 . Rancangan penyuluhan dalam penelitian ini adalah: (1) materi yang digunakan adalah pembuatan dan penggunaan pupuk kompos pada usahatani padi, (2) metode yang digunakan adalah visual, audio visual, ceramah, dan diskusi, (3) serta media yang digunakan adalah film. 


\section{DAFTAR PUSTAKA}

Agustian, A.; Benny, R. (2006). Persepsi Petani terhadap Pemanfaatan Bokashi Jerami pada Tanaman Ubi Jalar. Jurnal Agrisistem, 2(2), 46-53.

Azwar, S. (2015). Penyusunan Skala Psikologi Edisi 2. Pustaka Belajar.

Azwar, S. (2016). Sikap Manusia, Teori dan Pengukurannya (Kedua). Pustaka Pelajar.

Basri, H. (2016). Analisis Persepsi Petani Terhadap Pemanfaatan Bokashi Pada Pertanaman Padi Sawah. AGRISEP, 15(2), 135-142.

Gama, I.G.M.; Oktaviani, R.; Arifin, A. (2016). Analisis Kepuasan Petani Terhadap Penggunaan Pupuk Organik Pada Tanaman Padi. Jurnal Agro Ekonomi, 34(2), 105122.

Hadi, S.; Akhmadi, A.N.; Prayuningsih, H. (2019). Peran Kelompok Tani dan Persepsi Petani terhadap Penerapan Budidaya Padi Organik di Kabupaten Jember. Jurnal Penyuluhan, 15(2), 154-168.

Indriani, Y. H. (2002). Membuat Kompos Secara Kilat. PT Penebar Swadaya.

Intisar;, Ayu, S.M.; Rosnina; Nuryanti, D. M. (2019). Analisis Persepsi Petani Terhadap Pupuk Organik Di Kecamatan Walenrang Utara Kabupaten Luwu Utara. Journal TABARO, 3(2), 354-359.

Nasir. (2008). Teknik Pembuatan Bokasi. CV Pustaka Setia.

Rukmana, R. (2007). Bertanam Petsai dan Sawi. Kanisius.

Sam, U.S.; Ali, M.S.S.; Arsyad, M. (2018). Persepsi Petani Terhadap Pertanian Lada Organik Dan Non-Organik: Studi Kasus Di Desa Swatani, Kecamatan Rilau Ale,Kabupaten Bulukumba, Provinsi Sulawesi Selatan. Jurnal Sosial Ekonomi Pertanian, 14(2), 121-132.

Sobur, A. (2016). Psikologi Umum. Pustaka Setia.

Sugiyono. (2010). Metode Penelitian Pendidikan Pendekatan Kuantitatif, Kualitatif, dan $R \& D$. Alfabeta.

Tedjaningsih, T.; Suyudi; Nuryaman, H. (2017). Persepsi Petani Terhadap Penggunaan Pupuk Organik Pada Usahatani Mendong. Mimbar Agribisnis Jurnal Pemikiran Masyarakat Ilmiah Berwawasan Agribisnis, 3(1), 64-72.

Wasito; Sarwani, M.; Ananto, E. E. (2010). Persepsi dan Adopsi Petani terhadap Teknologi Pemupukan Berimbangpada Tanaman Padi dengan Indeks Pertanaman 300. Penelitian Pertanian Tanaman Pangan, 29(03), 157-165. 